\title{
Individuality in the female songs of wild Silvery Gibbons (Hylobates moloch) on Java, Indonesia
}

\author{
Robert Dallmann \& Thomas Geissmann \\ Institute of Zoology, Tierärztliche Hochschule Hannover, Germany. E-mail: robert@dallmanns.de
}
Keywords: Hylobates moloch, Silvery Gibbon, song, individuality, vocalization, Hylobates agilis, Hylobates klossii

\begin{abstract}
This is the first study comparing individuality in the songs among several gibbon species. All gibbon species produce loud, long and elaborate song bouts in the early morning. Silvery gibbons (Hylobates moloch) differ from other hylobatids, however, in that duet song bouts are absent, male singing appears to be uncommon and most song bouts are female solo songs. Consistent individual differences easily distinguish neighboring females in the field, and it has been suggested that female individuality is particularly high in $H$. moloch in order to compensate for the lack of a family-labeling male song. The aim in this study is to test this hypothesis by quantifying individuality in $H$, moloch and comparing it with data on song individuality in two other

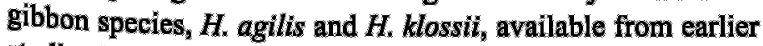
studies (Haimoff and Gittins, 1985; Haimoff and Tilson, 1985). The focus in those studies had been on the great call (i.e. the most stereotypical song phrase produced by gibbon females) and individual variation of several variables (such as duration and frequency range of selected great call notes) had been determined. We exactly replicated each of those studies with great calls of $H$. moloch, which were tape-recorded in Ujung Kulon and Gunung Pangrango. According to the working hypotheses, individuality should be highest in $H_{x}$ moloch, lower in $H$. klossil (male singing is common) and lowest in $H$. agilis (male singing and duets are common). Results: We found a statisticallysignificant degree of inter-individual variability in most great call variables of $H$, moloch, which is higher than that of $H$. klossi but lower than that of $H$,agilis. Our results do not sunport the hypothesis that $H$. moloch females compensate for the rarity of male song contributions with an elevated degree of individuality in their singing. Instead, we suggest that the amount of great call individuality may be compromised by the amount of a trill component exhibited by various species of the lar group of gib-
bons.
\end{abstract}

\section{Contents}

$\begin{array}{ll}\text { Introduction } & 41 \\ \text { Material and methods } & 42 \\ \text { Study animals } & 42 \\ \text { Recording and analysis } & 43 \\ \text { Data collecting } & 43 \\ \text { Statistics } & 45 \\ \text { Results } & 45 \\ \text { Comparison sets A and B } & 45 \\ \text { Comparison set C } & 45 \\ \text { Comparison between all three sets } & 45 \\ \text { Discussion } & 46 \\ \text { Conclusions } & 49 \\ \text { Acknowledgements } & 49 \\ \text { References } & 49\end{array}$

\section{Introduction}

Gibbons are distributed throughout the tropical rain forests of South-east Asia (Chivers, 1977; Geissmann, 1995; Marshall and Sugardjito, 1986) and live in monogamous, territorial family groups typically consisting of an adult pair and 1-3 immature offspring (Chivers, 1977, 1989; Leighton, 1987). All species of gibbons are known to produce elaborate, loud, long and stereotyped patterns of vocalization often referred to as "songs" (Geissmann, 1993, 1995; Haimoff, 1984; Marshall and Marshall, 1976). These song bouts are preferentially produced in the early morning and have a duration of about 10-30 minutes. In most species, mates typically *combine their species-specific and often sex-specific vocalizations to produce well-patterned duets. In the lar group of gibbons (e.g. $H$. agilis), mated males 
additionally produce solo song bouts. In two species (H. klossii, H. moloch), males and females produce no duets, but solo songs only (Geissmann, 1993, 1995, in prep.; Geissmann and Nijman, 1999, 2000). The silvery gibbon is even more unusual among hylobatids, because of the rarity of male singing (Geissmann, in prep.; Geissmann and Nijman, 1999, 2000). In this species, adult females appear to be the vocal " "representative" of the family" (Kappeler, 1984a, p. 388).

Acoustic differences have repeatedly been reported to exist between vocalizations produced by individual primates, including gibbons (Haimoff and Gittins, 1985; Haimoff and Tilson, 1985; Mitani, 1996; Snowdon, 1986; Waser, 1982). Quantitative data on the individuality of female songs, however, appear to be available only for two gibbon species, H. agilis and $H$. klossii (Haìmoff and Gittins, 1985; Haimoff and Tilson, 1985). A high degree of individuality has been reported for H. moloch (Geissmann and Nijman, 1999, 2000; Kappeler, 1981, 1984a), and it has been suggested that female individuality may be particularly high in this gibbon species, "thus compensating for the lack of a family-labeling male song" (Marshall and Sugardjito, 1986, p. 157).

If correct, this hypothesis would let us predict that individuality in female songs should be low in those species which produce both duets and male solo songs but no female solo songs (e.g. $H$. agilis), higher in that gibbon species which does not duet but produces separated solo songs of males and females $(H$. klossii), and highest in the species in which duets are absent, males sing only rarely and most of the singing is provided by the females (i.e. $H$. moloch). The aim in our study is to test this hypothesis by quantifying individuality in wild $H$. moloch and comparing it with data on song individuality in $H$. agilis and $H$. klossii available from earlier studies (Haimoff and Gittins, 1985; Haimoff and Tilson, 1985).

\section{Material and methods}

\section{Study animals}

In order to ensure the comparability of our results with those of the two earlier studies (Haimoff and
Gittins, 1985; Haimoff and Tilson, 1985), we exactly replicated each of them with our study animals. This dictated the whole design of our study. We used the same number of individuals, analysed the same number of great calls of each animal, measured analogous variables and used the same statistical tests as the previous studies. Because the earlier study on $H$. agilis (Haimoff and Gittins, 1985) had included data from two different localities, we also included two localities in our comparison samples of $\mathrm{H}$. moloch, and the selected localities (Kalejatan and Gunung Pangrango on Java) were about the same distance apart from each other as those in the earlier study (Sungai Dal and Ulu Muda on peninsular Malaysia). The localities where taperecordings were made are shown in Fig. 1.

Kalejatan is located near the westernmost tip of Java (Indonesia) in the Ujung Kulon-Gunung Honje Nature Reserve. The gibbons of Kalejatan were tape-recorded during a long term study in 1976 (Kappeler, 1981, 1984a). Songs of 75 great calls of 5 females (referred to as ka5-ka9 in the following) were analysed in this study.

The second locality is situated on the northeastern slopes of the Gunung Pangrango, about 150 $\mathrm{km}$ east of Kalejatan. Tape-recordings of 3 females (referred to as pa1-pa3) were made by one of us (TG) in September 1998. A total of 68 great calls from these individuals could be sonagraphed.

The number of individuals and great calls used for this study are listed in Table 1. Because the Kruskal-Wallis one-way analysis of variance by ranks is quite susceptible to variations in the sample size, we chose an identical number of animals and great calls / individual for statistical analysis as the previous studies (Haimoff and Gittins, 1985; Haimoff and Tilson, 1985). We created 3 comparison sets of data (A, B, and C), one each for comparison with $H$. agilis from Sungai Dal, $H$. agilis from Ulu Muda, and $H$. klossii from Siberut. For comparison with $H$. agilis, we used all 3 specimens from Gunung Pangrango and 5 from Kalejatan (Table 1, comparison set A), thus simulating the 3 H. agilis from Ulu Muda and the 5 from Sungai Dal studied by Haimoff and Gittins (1985). Like that study, we choose 5 great calls of each female for comparison with Ulu Muda and 3-10 great calls I female for comparison with Sungai Dal (Table 1, comparison set B). 


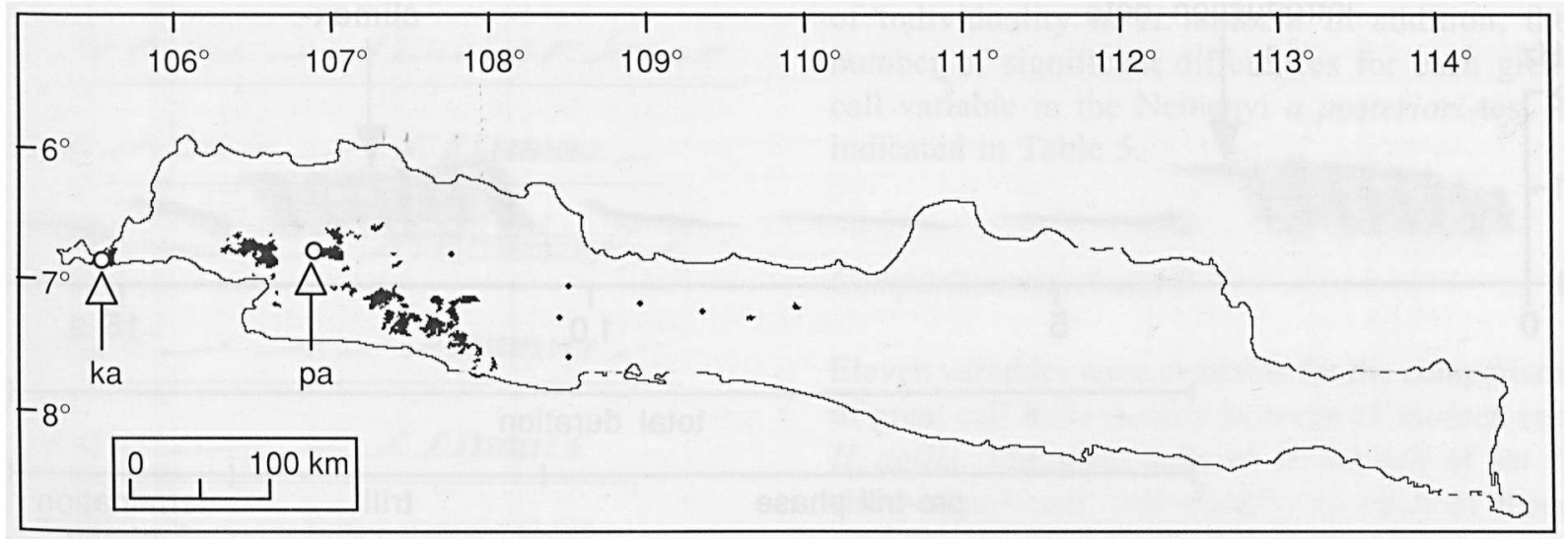

Fig. 1. Map of Java showing the two localities (arrows) where gibbon songs were tape-recorded. Black spots symbolize forests inhabited by gibbons (after Kappeler, 1984b, supplemented). Abbreviations: ka = Kalejatan; pa = Gunung Pangrango.

Table 1. Origin and number of great calls analysed in this study for comparison with those of $H$. agilis and $H$. klossii (Haimoff and Gittins, 1985; Haimoff and Tilson, 1985).

\begin{tabular}{|c|c|c|c|c|}
\hline Comparison set & $\begin{array}{l}\text { Population of } \\
\text { H. moloch }\end{array}$ & Individuals & $\begin{array}{l}\text { Number of } \\
\text { great calls / individual }\end{array}$ & $\begin{array}{l}\text { Comparison with previous } \\
\text {. studies }\end{array}$ \\
\hline A & Kalejatan & $\frac{\frac{\mathrm{ka} 6, \mathrm{ka} 7, \mathrm{ka} 8}{\mathrm{ka} 5}}{\mathrm{ka} 9}$ & $\frac{10}{5}$ & $\begin{array}{l}\text { H. agilis from Sungai Dal } \\
\text { (Haimoff \& Gittins, 1985) }\end{array}$ \\
\hline B & Gunung Pangrango & pal, pa2, pa3 & 5 & $\begin{array}{l}\text { H. agilis from Ulu Muda } \\
\text { (Haimoff \& Gittins, 1985) }\end{array}$ \\
\hline $\mathrm{C}$ & Kalejatan & $\frac{\mathrm{ka} 6, \mathrm{ka} 7, \mathrm{ka} 8}{\mathrm{ka} 5}$ & $\frac{10}{8}$ & $\begin{array}{l}\text { H. klossii } \\
\text { (Haimoff \& Tilson, 1985) }\end{array}$ \\
\hline
\end{tabular}

In their study on $H$. klossii, Haimoff and Tilson (1985) had analysed 10 great calls each of 3 individuals and 8 great calls of a fourth one. For comparison, we analysed the same numbers of great calls of four gibbons from Kalejatan (Table 1, comparison set $\mathrm{C}$ ).

\section{Recording and analysis}

Songs of silvery gibbons from Ujung Kulon were recorded with a UHER REPORT 4200 tape recorder and a NIVICO IVC directional microphone, those from Gunung Pangrango were made with a SONY WM-D6C cassette recorder and a JVC MZ-707 directional microphone.

The sound material was digitised with a sample rate of $11 \mathrm{kHz}$ and a sample size of 16 bit. Time versus frequency displays (sonagrams) of tape- recorded vocalizations were generated using the Canary software version 1.2.4 on an Apple personal computer (Power Macintosh G3). The FFT size of the sonagrams was 2048 points with an overlap of $75 \%$ and a frame length of 1024 points (Charif et al., 1995).

\section{Data collecting}

The female song bout of $H$. moloch consists of 2 different acoustic components: (1) great calls phrases, and (2) single wa-notes and phrases of $w a$-notes. In contrast to the more variable organization of wa-phrases, great calls are highly stereotypic phrases of the female song. We identify three basic phases in the great calls of $H$. moloch females (Fig. 2): (i) a pre-trill phase, (ii) a trill and (iii) the termination phase. Since females of 


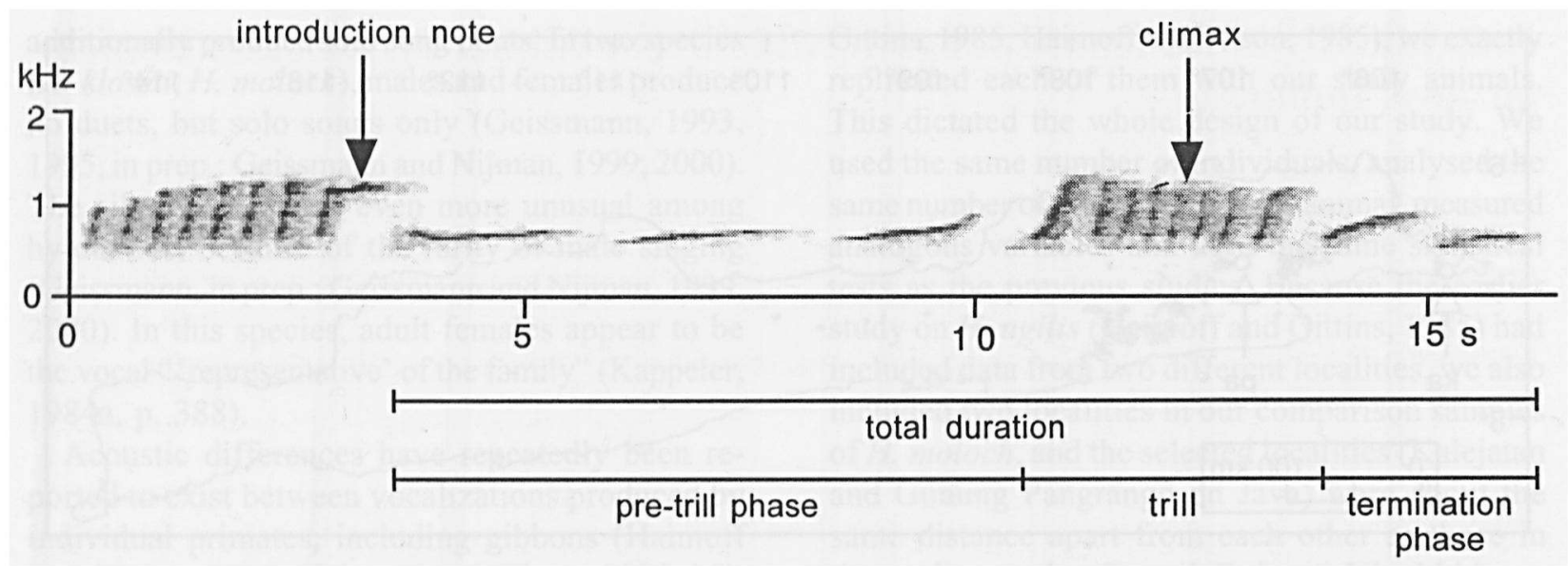

Fig. 2. Sonagram of a great call phrase produced by a female silvery gibbon, illustrating the 3 main phases (i.e. pre-trill phase, trill phase, and termination phase) which are typical features of this species great calls, and the variables measured.

Table 2. Great call variables for Hylobates moloch used in the" present study and corresponding variables for $H$. agilis and $H$. klossii used in previous studies.

\begin{tabular}{|c|c|c|}
\hline $\begin{array}{l}\text { Variable for H. moloch } \\
\text { Dallmann \& Geissmann (this study) }\end{array}$ & $\begin{array}{l}\text { H. agilis } \\
\text { Haimoff \& Gittins (1985) }\end{array}$ & $\begin{array}{l}\text { H. klossii } \\
\text { Haimoff \& Tilson (1985) }\end{array}$ \\
\hline 1. Total duration of great call (s) & Total duration & Total duration of great calls \\
\hline 2. Frequency range of entire great call $(\mathrm{Hz})$ & Frequency exploitation & Frequency band exploited during great calls \\
\hline 3. Number of pre-trill phase notes & No. of intro. phase notes & Total number of notes before the trill \\
\hline 4. Duration of first note (s) & - & Duration of first note \\
\hline (2) & Combined dur. intro. phase notes & - \\
\hline 5. Frequency range of first note $(\mathrm{Hz})$ & - & Frequency modulation of first note \\
\hline 6. Duration of second note (s) & - & Duration of second note \\
\hline 7. Frequency range of second note $(\mathrm{Hz})$ & - & Frequency of second note \\
\hline 8. Duration of pre-trill phase (s) & Duration intro. phase & Total duration before the trill \\
\hline 9. Duration of first note of trill (s) & Duration inflective note & - \\
\hline 10. Frequency range of first note of trill $(\mathrm{Hz})$ & $\begin{array}{l}\text { Frequency modulation inflective } \\
\text { note }\end{array}$ & - \\
\hline 11. Max. frequency of first note of trill $(\mathrm{Hz})$ & Peak frequency inflective note & - \\
\hline 12. Min. frequency range in trill $(\mathrm{Hz})$ & Peak frequency climax note & - \\
\hline 13. Duration of the trill (s) & - & Total duration of the trill \\
\hline 14. Number of notes during trill & - & Total number of notes during the trill \\
\hline $\begin{array}{l}\text { 15. Number of notes during trill / } \\
\text { duration trill }\left(\mathrm{s}^{-1}\right)\end{array}$ & - & Notes per second during the trill \\
\hline 16. Max. note speed in trill $\left(\mathrm{s}^{-1}\right)$ & Duration climax note & Notes per second during the climax \\
\hline 17. Number of termination phase notes & No. of post-climax notes & Total number of post-trill notes \\
\hline 18. Duration of termination phase (s) & Duration post-climax phase & Total duration of post-trill period \\
\hline
\end{tabular}

$H$. moloch may occasionally abort a great call, a song bout may also contain great call fragments which were not included in the analysis.

Previous studies on individuality of gibbon songs analysed the great call exclusively, because it is the longest and most standardised part of the female's song repertoire (Haimoff and Tilson, 1985). In the present study, the great calls of

\section{H. moloch females were analysed.}

Twenty variables of the great call were quantified and measured in a similar manner as in the earlier studies on $H$. agilis and $H$. klossii (Haimoff and Gittins, 1985; Haimoff and Tilson, 1985). A description of our great call variables and those defined in the earlier studies is presented in Table 2. 


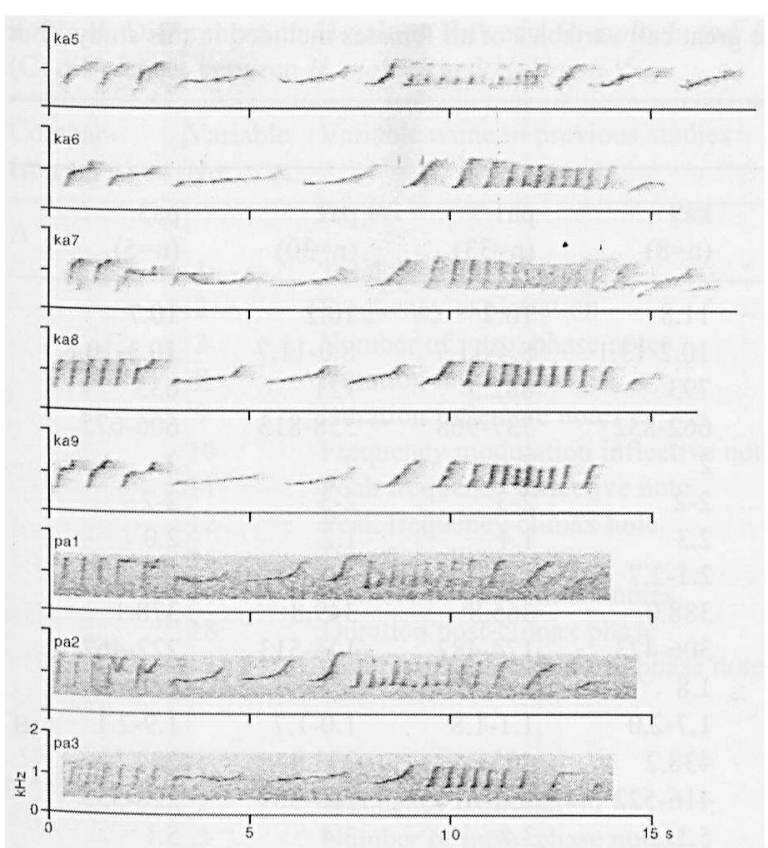

Fig. 3. Representative great calls by the 8 Hylobates moloch females from Kalejatan (ka) and Gunung Pangrango (pa) studied here.

\section{Statistics}

In order to demonstrate individuality among study animals, we used the Kruskal-Wallis one-way analysis of variance by ranks (Kruskal and Wallis, 1952), as in Haimoff and Gittins (1985) and Haimoff and Tilson (1985). To this we added the Nemenyi a posteriori test (Köhler, 1995). This test can only be carried out on variables which are significant in the Kruskal-Wallis test. All tests used were twotailed, and the null hypothesis was rejected at $\mathrm{p}=0.05$.

\section{Results}

Figure 3 shows sonagrams of a typical great call of each study animal. Medians and ranges of the various measured great call variables for all available great calls are listed in Table 3 .

After having formed three comparison sets of great calls (A, B, C), as described above, we carried out a Kruskal-Wallis one-way analysis of variance by ranks with each set. The results are shown in Table 4. Most variables show a significant degree of individuality in $H$. moloch. In addition, the number of significant differences for each great call variable in the Nemenyi a posteriori test is indicated in Table 5.

\section{Comparison sets $A$ and $B$}

Eleven variables were available for the comparison of great call individuality between $H$. moloch and $H$. agilis. The great calls of $H$. moloch of set A show significant individuality in each of these variables (Kruskal-Wallis test, Table 4A). The great calls of set $B$ are significant in 7 of 11 variables (Table 4B); only variables $3,9,11$ and 18 are not significant. Only variable 18 is among the three least significant variables in both sets. These results are confirmed in the Nemenyi a posteriori test (Table 5). None of the females of data set A could be distinguished in variables 17 and 18 .

\section{Comparison set $C$}

As shown in Table $4 \mathrm{C}$, all 14 great call variables show significant individuality except one (variable 18 ), and 10 of them are highly significant $(\mathrm{p}<$ $0.001)$. Similar to the results in data set $B$, variable 18 is not significant in the Kruskal-Wallis test, and variable 17 shows no significant dyads in the Nemenyi a posteriori test (Table 5).

\section{Comparison between all three sets}

In order to compare $H$. moloch with $H$. agilis and $H$. klossii, respectively, we determined which species had the higher H-value in the Kruskal-Wallis test for each variable (Table 5). A higher $\mathrm{H}$-value in this nonparametric test indicates a higher degree of inter-individual differences. The $\mathrm{H}$-value differences are plotted in Fig. 4 for all 3 data sets. In the graph, a major difference becomes apparent between data sets $\mathrm{A}$ and $\mathrm{B}$ on the one hand and data set $\mathrm{C}$ on the other. Hylobates moloch has lower " $H$-values than $H$. agilis in 8 out of 11 variables (data set A) and in 7 out of 11 variables (data set B). In the comparison with $H$. klossii, the situation 
Table 3. Measurements (median and range) from the sonagrams of the great call variables of all females included in this study. (For a description of the variables see Table 2).

\begin{tabular}{|c|c|c|c|c|c|c|c|c|}
\hline \multirow{2}{*}{$\begin{array}{l}\text { Variable } \\
\text { No. }\end{array}$} & \multicolumn{8}{|l|}{ Individual } \\
\hline & $\begin{array}{l}\text { ka5 } \\
(n=5)\end{array}$ & $\begin{array}{l}\mathrm{ka6} \\
(\mathrm{n}=23) \\
\end{array}$ & $\begin{array}{l}\text { ka7 } \\
(n=27)\end{array}$ & $\begin{array}{l}\mathrm{ka8} \\
(\mathrm{n}=12)\end{array}$ & $\begin{array}{l}\mathrm{ka9} \\
(\mathrm{n}=8)\end{array}$ & $\begin{array}{l}\text { pal } \\
(n=33)\end{array}$ & $\begin{array}{l}\text { pa2 } \\
(n=30)\end{array}$ & $\begin{array}{l}\text { pa3 } \\
(\mathrm{n}=5)\end{array}$ \\
\hline \multirow[t]{2}{*}{1} & 13.7 & 12.2 & 12.3 & 11.0 & 11.8 & 10.7 & 10.2 & 10.7 \\
\hline & $12.6-14.9$ & $9.8-14.1$ & $10.7-13.7$ & $10.0-13.3$ & $10.2-13.1$ & $8.4-11.7$ & $8.0-11.7$ & $10.3-10.8$ \\
\hline 2 & $\begin{array}{l}717 \\
687-788\end{array}$ & $\begin{array}{l}769 \\
710-852\end{array}$ & $\begin{array}{l}815.5 \\
751-918\end{array}$ & $\begin{array}{l}731.5 \\
698-797\end{array}$ & $\begin{array}{l}793 \\
662-832\end{array}$ & $\begin{array}{l}862.5 \\
737-968\end{array}$ & $\begin{array}{l}721 \\
558-813\end{array}$ & $\begin{array}{l}633 \\
606-675\end{array}$ \\
\hline \multirow[t]{2}{*}{3} & 2 & 2 & 3 & 3 & 2 & 2 & 2 & 2. \\
\hline & $2-2$ & $2-3$ & $2-3$ & 3-3 & $2-2$ & $2-3$ & $2-3$ & $2-2$ \\
\hline \multirow[t]{2}{*}{4} & 2.0 & 3.0 & 2.4 & 1.9 & 2.3 & 1.4 & 1.2 & 2.0 \\
\hline & $0.9-2.2$ & $2.1-3.4$ & $1.9-3.3$ & $1.6-2.0$ & $2.1-2.7$ & $1.2-1.8$ & $1.0-1.5$ & $1.4-2.0$ \\
\hline \multirow[t]{2}{*}{5} & 349.3 & 460.8 & 450.1 & 381.0 & 388.0 & 365.8 & 349.8 & 378.1 \\
\hline & $267-520$ & 299-727 & $316-521$ & $217-471$ & $306-423$ & $174-482$ & $174-513$ & $222-462$ \\
\hline \multirow[t]{2}{*}{6} & 1.8 & 1.9 & 2.0 & 1.6 & 1.8 & 1.5 & 1.2 & 2.0 \\
\hline & $1.6-2.3$ & $1.6-2.3$ & $1.6-2.4$ & $1.4-1.8$ & $1.7-2.0$ & $1.1-1.8$ & $1.0-1.7$ & $1.9-2.1$ \\
\hline \multirow[t]{2}{*}{7} & 413.4 & 413.6 & 458.2 & 424.3 & 438.2 & 495.1 & 373.8 & 292.3 \\
\hline & $244-512$ & $335-501$ & $368-581$ & 299-456 & $416-522$ & 251-614 & 229-509 & $228-335$ \\
\hline \multirow[t]{2}{*}{8} & 4.8 & 5.9 & 6.7 & 5.7 & 5.1 & $\begin{array}{l}3.8 \\
3.4-4.7\end{array}$ & 3.4 & 5.1 \\
\hline & $4.5-5.0$ & $5.0-7.4$ & $4.8-8.1$ & $\begin{array}{l}5.1-6.3 \\
0.6\end{array}$ & $\begin{array}{l}4.8-5.6 \\
1.1\end{array}$ & $\begin{array}{l}3.4-4.7 \\
0.9\end{array}$ & $\begin{array}{l}2.9-5.1 \\
0.6\end{array}$ & $\begin{array}{l}4.8-5.2 \\
0.8\end{array}$ \\
\hline 9 & $\begin{array}{l}0.8 \\
0.8-0.9\end{array}$ & $\begin{array}{l}1.2 \\
0.8-1.3\end{array}$ & $\begin{array}{l}0.6 \\
0.4-1.0\end{array}$ & $\begin{array}{l}0.6 \\
0.5-0.9\end{array}$ & $\begin{array}{l}1.1 \\
1.0-1.2\end{array}$ & $\begin{array}{l}0.9 \\
0.4-1.5\end{array}$ & $0.3-1.0$ & $\begin{array}{l}0.0 \\
0.7-1.1\end{array}$ \\
\hline \multirow[t]{2}{*}{10} & $\begin{array}{l}0.8-0.9 \\
658.8\end{array}$ & $\begin{array}{l}0.8-1.3 \\
644.7\end{array}$ & $\begin{array}{l}0.4-1.0 \\
683.8\end{array}$ & $\begin{array}{l}0.5-0.9 \\
616.7\end{array}$ & $\begin{array}{l}1.00-1.2 \\
642.5\end{array}$ & 690.3 & 618.8 & 469.4 \\
\hline & $636-681$ & $588-729$ & $627-856$ & $572-650$ & $535-706$ & $581-796$ & $229-694$ & $441-539$ \\
\hline \multirow[t]{2}{*}{11} & 1367.2 & 1344.4 & 1372.0 & 1309.0 & 1338.5 & 1474.3 & 1314.0 & 1239.0 \\
\hline & $1350-1375$ & $1308-1423$ & $1291-1496$ & $1270-1358$ & $1292-1386$ & $1296-1605$ & $881-1347$ & $1228-1265$ \\
\hline \multirow[t]{2}{*}{12} & 497 & 475 & 507.5 & 495 & 449.5 & 617.5 & 342.5 & 450 \\
\hline & $485-503$ & $401-519$ & $413-587$ & 433-539 & $365-502$ & $354-700$ & $231-553$ & $400-464$ \\
\hline \multirow[t]{2}{*}{13} & 4.8 & 5.3 & 4.3 & 4.4 & 5.3 & 4.8 & 4.7 & 4.0 \\
\hline & $4.4-5.4$ & $4.5-6.0$ & $3.0-6.4$ & $3.3-5.6$ & $4.5-5.8$ & $3.1-6.0$ & $3.5-6.2$ & $3.7-4.6$ \\
\hline \multirow[t]{2}{*}{14} & 10 & 10.5 & 11 & 10 & 11 & 13 & 16 & 11 \\
\hline & $10-10$ & $8-13$ & $8-15$ & $9-13$ & $8-13$ & $10-18$ & $12-20$ & $8-12$ \\
\hline \multirow[t]{2}{*}{15 . } & 2.08 & 1.92 & 2.57 & 2.27 & 2.08 & 2.72 & 3.40 & 2.78 \\
\hline & $1.8-2.2$ & $1.2-3.5$ & $2.0-2.9$ & $1.6-3.9$ & $1.4-2.4$ & $1.6-5.7$ & $1.9-5.6$ & $1.7-3.2$ \\
\hline \multirow[t]{2}{*}{16} & 1.11 & 0.87 & 0.88 & 0.97 & 0.86 & 0.90 & 0.69 & 0.83 \\
\hline & $1.0-1.1$ & $0.8-1.0$ & $0.7-1.0$ & $0.9-1.1$ & $0.7-0.9$ & $0.7-1.1$ & $0.5-1.1$ & $0.7-1.3$ \\
\hline \multirow[t]{2}{*}{17} & 3 & 1 & 1 & 1.5 & 1.5 & 2 & 2 & 2 \\
\hline & $2-3$ & $1-2$ & $1-2$ & $1-2$ & $1-2$ & $1-3$ & $1-4$ & $1-2$ \\
\hline \multirow[t]{2}{*}{18} & 4.5 & 0.8 & 0.9 & 1.0 & 1.4 & 2.1 & 1.6 & 1.7 \\
\hline & $1.8-5.1$ & $0.3-1.9$ & $0.5-2.5$ & $0.7-1.8$ & $0.6-2.0$ & $1.0-2.8$ & $0.6-2.6$ & $0.9-2.0$ \\
\hline
\end{tabular}

is reversed: Hylobates moloch has higher H-values than $H$. klossil in 12 out of 14 tested variables. Only in two variables does $H$. klossii exhibit higher $\mathrm{H}$-values than $H$. moloch, and both these variables refer to the termination phase of the great call (Nos. 17 and 18), which has been described as the most intra-individually variable part in the great call of H. moloch (Kappeler, 1984a).

\section{Discussion}

Structural variability of the great calls among silvery gibbons $(H$. moloch $)$ was tentatively proposed to occur by Geissmann and Nijman $(1999,2000)$ and Kappeler (1981, 1984a). The great calls of $H$. moloch are characterized by specific quantifiable variables. These physical features exhibit statistically-significant individuality among the singing females. The evidence of the statistical tests con- 


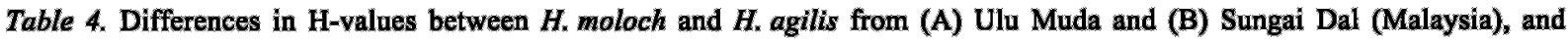
(C) differences between $H$. moloch and $H$. klossit. ${ }^{1}$

\begin{tabular}{|c|c|c|c|c|c|}
\hline $\begin{array}{l}\text { Compar- } \\
\text { ison set }\end{array}$ & $\begin{array}{l}\text { Variable } \\
\text { No. }\end{array}$ & Variable name in previous studies & $\begin{array}{l}\text { H-values of } \\
H_{n} \text { moloch }\end{array}$ & $\begin{array}{l}\text { Published } \\
\text { H-values of }\end{array}$ & $\begin{array}{l}\text { Difference of } \\
\text { H-values }\end{array}$ \\
\hline $\mathbf{A}$ & $\begin{array}{c}1 \\
2 \\
3 \\
8 \\
9 \\
10 \\
11 \\
12 \\
16 \\
17 \\
18\end{array}$ & $\begin{array}{l}\text { Total duration } \\
\text { Frequency exploitation } \\
\text { Number of intro. phase notes } \\
\text { Duration intro. phase } \\
\text { Duration inflective note } \\
\text { Frequency modulation inflective note } \\
\text { Peak frequency inflective note } \\
\text { Peak frequency climax note } \\
\text { Duration climax note } \\
\text { Number of post-climax notes } \\
\text { Duration post-climax phase } \\
\text { Combined duration intro. phase notes }\end{array}$ & $\begin{array}{l}20.42 * * * \\
21.76 * * * \\
20.15 * * * \\
12.50 * \\
27.56 * * \\
24.38 * * * \\
21.50^{* * *} \\
17.87 * * \\
24.19 * * \\
12.46 * \\
14.18 * * \\
-\end{array}$ & $\begin{array}{l}\text { H. agilis } \\
34.49 * * * \\
31.46 * * * \\
36.99 * * * \\
34.94 * * * \\
22.85 * * * \\
18.74 * * * \\
21.33^{* * *} \\
30.89 * * * \\
26.37 * * * \\
24.66 * * * \\
24.36 * * * \\
34.52^{* * *}\end{array}$ & $\begin{array}{r}-14.07 \\
-9.70 \\
-16.84 \\
-22.44 \\
4.71 \\
5.64 \\
0.17 \\
-13.03 \\
-2.18 \\
-10.46 \\
-14.34 \\
-\end{array}$ \\
\hline $\mathbf{B}$ & $\begin{array}{c}1 \\
2 \\
3 \\
8 \\
9 \\
10 \\
11 \\
12 \\
16 \\
17 \\
18\end{array}$ & $\begin{array}{l}\text { Total duration } \\
\text { Frequency exploitation } \\
\text { Number of intro. phase notes } \\
\text { Duration intro. phase } \\
\text { Duration inflective note } \\
\text { Frequency modulation inflective note } \\
\text { Peak frequency inflective note } \\
\text { Peak frequency climax note } \\
\text { Duration climax note } \\
\text { Number of post-climax notes } \\
\text { Duration post-climax phase } \\
\text { Combined duration intro. phase notes }\end{array}$ & $\begin{array}{l}7.46^{*} \\
10.21 * * \\
0.00 \\
18.73 * * * \\
5.18 \\
10.50^{* *} \\
5.12 \\
12.50^{* *} \\
9.64^{* *} \\
6.70^{*} \\
4.74 \\
-\end{array}$ & $\begin{array}{l}H_{.} \text {agilis } \\
10.30^{* *} \\
10.05^{* *} \\
12.99^{* * *} \\
11.83^{* *} \\
5.39 \\
11.80^{* *} \\
11.96^{* *} \\
9.38^{* *} \\
8.49^{*} \\
11.25^{* *} \\
11.82^{* *} \\
9.36^{*}\end{array}$ & $\begin{array}{r}-2.84 \\
0.16 \\
-12.99 \\
6.90 \\
-0.21 \\
-1.30 \\
-6.84 \\
3.12 \\
1.13 \\
-7.23 \\
-7.08\end{array}$ \\
\hline $\mathrm{C}$ & $\begin{array}{l}1 \\
2 \\
3 \\
4 \\
5 \\
6 \\
7 \\
8 \\
13 \\
14 \\
15 \\
16 \\
17 \\
18\end{array}$ & $\begin{array}{l}\text { Total duration of entire great calls } \\
\text { Frequency band exploited during great calls } \\
\text { Total number of notes before the trill } \\
\text { Duration of first note } \\
\text { Frequency modulation of first note } \\
\text { Duration of second note } \\
\text { Frequency of second note } \\
\text { Total duration before the trill } \\
\text { Total duration of the trill } \\
\text { Total number of notes during the trill } \\
\text { Notes / second during the trill } \\
\text { Notes / second during the climax } \\
\text { Total number of post-trill notes } \\
\text { Total duration of post-trill period }\end{array}$ & $\begin{array}{l}18.46 * * * \\
12.18 * \\
27.69 * * * \\
27.24 * * \\
17.71 * * * \\
30.64^{* * *} \\
18.23 * * * \\
33.61 * * * \\
21.75 * * * \\
12.89 * * \\
30.42 * * * \\
23.10^{* * *} \\
8.12 * \\
6.46\end{array}$ & $\begin{array}{c}H_{.} \text {klossil } \\
11.92^{* *} \\
10.80^{*} \\
15.46^{* * *} \\
10.13^{*} \\
2.67 \\
6.98 \\
3.98 \\
12.29 * * \\
8.15^{*} \\
10.01^{*} \\
13.40^{* *} \\
12.10^{* *} \\
13.20^{* *} \\
14.50^{* *}\end{array}$ & $\begin{array}{r}6.54 \\
1.38 \\
12.23 \\
17.11 \\
15.04 \\
23.66 \\
14.25 \\
21.32 \\
13.60 \\
2.88 \\
17.02 \\
11.00 \\
-5.08 \\
-8.04\end{array}$ \\
\hline
\end{tabular}

$1 *=p<0.05, * *=p<0.01, * * *=p<0.001$

ducted here clearly demonstrates that individuality exists throughout most aspects of the entire female great call.

Most measured variables show a significant degree of differences between great calls of different tested females. Solely variables 17 ("number of termination phase notes") and 18 ("duration of termination phase") show no significances at all in the Nemenyi tests with the three data sets. The extremely high intra-individual variability of this part of the great call has previously been mentioned by Kappeler (1984a) and appears to compromise individuality in this part of the great call.

The termination phase is usually produced with 
Table 5. Number of signiticant differences for each great call variable in the Nemenyi a posteriori test. Only variables which were significant in the Kruskal-Wallis test (Table 4) are included.

\begin{tabular}{llcl}
\hline $\begin{array}{l}\text { Compar- } \\
\text { ison set }\end{array}$ & $\begin{array}{l}\text { Compar- } \\
\text { ison with }\end{array}$ & $\begin{array}{l}\text { Number of } \\
\text { significant dyads }\end{array}$ & Variable No. \\
\hline A & H. agilis, & 0 & 17,18 \\
& Sungai Dal & 1 & 1,16 \\
& & 2 & $3,11,12$ \\
& & 4 & 8,2 \\
& & 4 & 9,10 \\
B & H. agilis, & 0 & - \\
& Ulu Muda & 1 & $1,8,2,10,12$ \\
& & 2 & 16 \\
C & H. klossii & 0 & 17 \\
& & 1 & $2,5,7,13,15$ \\
& & 3 & $1,4,16$ \\
& & 4 & $8,3,14$ \\
\hline
\end{tabular}

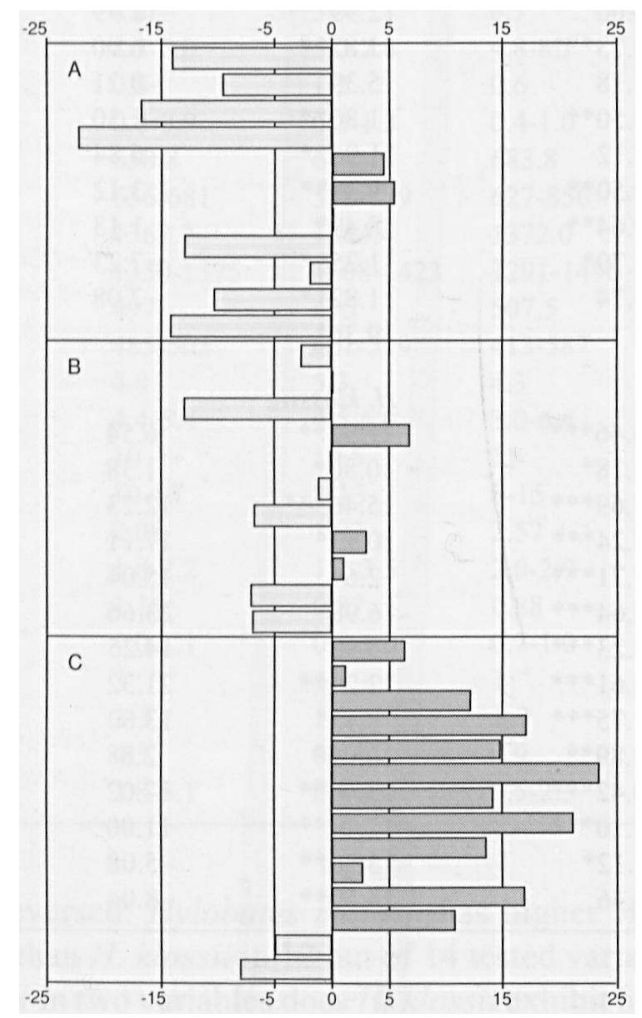

Fig. 4. Comparison of the H-values (from Table 3) between gibbon species for each great call variable: The horizontal axis shows the difference between the $\mathrm{H}$-value of $H$. moloch minus the corresponding $\mathrm{H}$-value of A) $H$. agilis from Sungai DaI; B) $H$. agilis from Ulu Muda; and C) $H$. klossii. Positive bars indicate a higher individuality in $H$. moloch, whereas negative bars indicate a higher individuality in $H$. agilis and $H$. klossii, respectively. Great call variables (vertical axis) appear in the same order as in Tables 2 and 4. decreasing amplitude and can only be heard in the singer's immediate vicinity. Because these soft notes are probably inaudible to neighbouring groups, it is less likely that they provide information on who is singing. Selection for individuality in these shortrange notes can be expected to be relaxed given the ability of recipients to use other sensory modalities to identify signallers. The same argument was also presented in a study on communication in wild chimpanzees, whose pant hoots (long-distance calls) showed greater within-individual stereotypy and between-individual variability than pant grunts (short-range calls) (Mitani et al., 1996).

In contrast to our findings in $\mathrm{H}$. moloch, Kloss's gibbons exhibit significant inter-individual differences at the end of the great call and the highest $\mathrm{H}$-values of all tested variables. Hylobates agilis, on the other hand, shows little inter-individual variability in the termination phase. Female agile gibbons appear to exhibit more inter-individual differences in the introduction phase than in the termination phase (Haimoff and Gittins, 1985). These differences between the three species may be related to differences in their great call structure. The great call of $H$. klossii includes a very fast and long central trill which may be more suited to convey information on the singer's stamina than about its identity. The trill is considerable shorter and slower in H. moloch, and virtually absent in H. agilis (Geissmann, 1993).

A reliable comparison of the degree of individuality in different parts of the great call would require larger samples of individuals and great calls. In addition, more variables would need to be measured, representing a more balanced amount of information on the different parts of the whole great call.

Although we were able to demonstrate individual differences in the great call of $H$. moloch females, it is unknown, whether gibbons can individually distinguish great calls of conspecifics. This could be investigated upon with the help of playback experiments. Furthermore, it is unknown, whether the individual differences remain stable over time.

Among gibbons, only in $H$. moloch is most of the singing provided by females. It has been predicted that female songs of this species would show a greater individuality than female songs of species with frequent male solo songs (such as $\mathrm{H}$. klossii 
and $H$. agilis) and male duet contributions (such as $H$. agilis) (Marshall and Sugardjito, 1986, p. 157). By using the same methods previously applied to great calls of $H$. agilis and $H$. klossii (Haimoff and Gittins, 1985; Haiimoff and Tilson, 1985), we were able to demonstrate that, in contrast to our study hypothesis, $\mathrm{H}$. moloch is not showing the highest degree of individuality in its female great calls. We conclude that the lack of male singing has not resulted in an elevated individuality in the female song of $H$. moloch.

This study is the first to compare song individuality among gibbon species. Our results do not indicate that great call individuality is related to either the amount of solo singing or the amount of male singing among the three species under comparison. We offer an alternative hypothesis. Great calls of the lar group of gibbons can be grouped into three classes (Geissmann 1993, p. 197; Marshall et al., 1984): Those of the soaring or wailing type $(H$, agilis, $H$. lar) consist of different, frequencymodulated note types which increase and decrease in frequency and are produced at slow speed with only slight variation in rhythm. The other extreme is represented by the bubbling or trilling type (H. klossii, H. muelleri, H. pileatus), mainly consisting of notes of increasing frequency which are produced with a pronounced acceleration in rhythm and which are climaxing in a long and fast bubbling trill. The great call of $H$. moloch is somewhat intermediate between the two extremes, because "it neither soars nor trills" (Marshall et al., 1984). It consists of notes of mainly increasing frequency uttered with an acceleration in rhythm, but only a short trill of moderate speed is reached. It appears reasonable to assume that species with a long and fast trill may exhibit less individuality because the trill consists of repetetive notes only. This may explain why $H$. klossii exhibits less great call individuality than $H$. agilis, and why $H$. moloch occupies and intermediate position. As suggested by Geissmann (1993, p. 198), the soaring great call type probably represents a derived characteristic whithin the lar group. It is possible that the trill

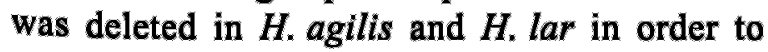
accomodate more individuality-coding notes in the great call. This hypothesis could be tested by analysing great call individuality in the remaining species of the lar group. If our hypothesis is correct, $H$. lar should exhibit an amount of individuality similar to that of $H$. agilis. Hylobates muelleri and $H$. pileatus, on the other hand, should exhibit a much lower amount of individuality, similar to that $H$. klossii or even lower, because their trill makes up the highest proportion of the great call duration among gibbons of the lar group.

\section{Conclusions}

1 We found a statistically-significant individuality in most great call variables of $H$. moloch, similar to the findings of previous studies on $H$. agilis and $H$. klossii.

2 The degree of individuality in $\mathrm{H}$. moloch is higher than in $H$. klossii, but lower than in H. agilis.

3 Our results do not support the hypothesis that $H$. moloch females compensate for the rarity of male singing with an elevated degree of individuality in their singing.

\section{Acknowledgements}

Additional tape-recordings used in the present study were kindly made available by $\mathrm{Dr}$. Markus Kappeler. We are greatful to $\mathrm{Dr}$. D.J. Chivers and Dr. B. Merker for reading and commenting on this manuscript.

\section{References}

Brockelmann WY, Srikosamatara S. 1984. Maintenance and evolution of social structure in gibbons. In: Preuschoft H, Chivers DJ, Brockelmann WY, Creel N, eds. The lesser apes. Evolutionary and behavioural biology. Edinburgh: Edinburgh University Press, 298-323.

Charif RA, Mitchell S, Clark CW. 1995. Canary 1.2 user's manual. New York: Cornell Laboratory of Ornithology, Ithaca.

Chivers DJ. 1989. The social behavior of the lesser apes. In: Seth PK, Seth S, eds. Perspectives in primate biology, vol. 3. New Delhi: Today and Tomorrow"s Printers and Publishers, 141-155.

Chivers DJ. 1977. The lesser apes. In: Prince Rainier III of Monaco, Bourne GH, eds. Primate conservation. New

- York: Academic Press, 539-598.

Chivers DJ. 1984. Feeding and ranging in gibbons: A sum- 
mary. In: Preuschoft H, Chivers DJ, Brockelmann WY, Creel N, eds. The lesser apes. Evolutionary and behavioural biology. Edinburgh: Edinburgh University Press, 267-281.

Geissmann T. 1993. Evolution of communication in gibbons (Hylobatidae). PhD thesis, Anthropological Institute, Philosoph. Faculty II, Zürich University.

Geissmann T. 1995. Gibbon systematics and species identification. Int. Zoo News 42: 467-501.

Geissmann T. in prep. Duett-splitting and the evolution of gibbon songs. Int. J. Primatol. (Manuscript submitted).

Geíssmann T, Nijman V. 1999. Singing behavior of the silvery gibbon (Hylobates moloch) in Central Java, Indonesia. Primate Report 54: 18-19 (Abstract only).

Geissmann T, Nijman V. 2000. Do male silvery gibbons have anything to say? - Haben männliche Sillbergibbons etwas zu sagen? Folia Primatol. 71: 225 (Abstract only).

Iaimoff EH, Tilson RL. 1985. Individuality in the female songs of wild Kloss" gibbons (Hylobates klossii) on Siberut Island, Indonesia. Folia Primatol. 44: 129-137.

Haimoff EH, Gittins SP. 1985. Individuality in the songs of wild agile gibbons (Hylobates agilis) of Peninsular Malaysia. Am. J. Primatol. 8: 239-247.

Ilaimoff EH. 1984. Acoustic and organizational features of gibbon songs. In: Preuschoft $\mathbf{H}$, Chivers DJ, Brockelmann WY, Creel N, eds. The lesser apes, Evolutionary and behavioural biology. Edinburgh: Edinburgh University Press, 333-353..

Kappeler M. 1981. The Javan silvery gibbon (Hylobates lar moloch), PhD thesis, Philisophisch-Naturwissenschaftliche Fakultăt, Universitất Basel.

Kappeler M. 1984a. Vocal bouts and territorial maintenance in the moloch gibbon. In: Preuschoft $\mathrm{H}$, Chivers DJ, Brockelmann WY, Creel N, eds. The lesser apes. Evolutionary and behavioural biology. Edinburgh: Edinburgh University Press, 376-389.

Kappeler M. 1984b. The gibbon in Java. In: Preuschoft $\mathrm{H}$,
Chivers DJ, Brockelmann WY, Creel N, eds. The lesser apes. Evolutionary and behavioural biology. Edinburgh: Edinburgh University Press, 19-31.

Köhler W. 1995. Biostatistik Einfürung in die Biometrie für Biologen und Agrarwissenschaftler, 2. Auflage, Berlin: Springer.

Kruskal WH, Wallis WA. 1952. Use of ranks in one-criterion variance analysis. J. Am. Statist. Assoc. 47: 583-621.

Leighton DR. 1987. Gibbons: Territoriality and monogamy. In: Smuts BB, Cheney DL, Seyfarth RM, Wrangham RW, Struhsaker TT, eds. Primate societies. Chicago and London:University of Chicago Press, 135-145.

Marshall JT, Marshall ER. 1976. Gibbons and their territorial songs. Science 193: 235-237.

Marshall, JT, Sugardjito, J, Markaya, M. 1984. Gïbbons of the lar group: Relationships based on voice. In: Preuschoft H, Chivers DJ, Brockelman WY, Creel, N, eds. The lesser apes. Evolutionary and behavioural biology. Edinburgh: Edinburgh University Press, 533-541.

Marshall, JT, Sugardjito J. 1986. Gibbon systematics. In: Swindler DR, Erwin J, eds. Comparative primate biology, vol. 1: Systematics, evolution, and anatomy. New York: Alan R. Liss, 137-185.

Mitani JC, Gros-Louis J, Macedonia JM. 1996. Selection for acoustic individuality within the vocal repertoire of wild chimpanzees. Int. J. Primatol. 17: 569-583.

Snowdon CT. 1986. Vocal communication. In: Mitchell DR, Erwin $\mathrm{J}$, eds. Comparative primate biology, vol. $2 A$ * Behavior, conservation, and ecology. New York: Alan R. Liss, 495-530.

Waser PM. 1982. The evolution of male loud calls among mangebeys and baboons. In: Snowdon CT, Brown $\mathbf{C H}$, Petersen MR, eds. Primate communication. Cambridge: Cambridge University Press, 117-143.

Received: 3 July 2000 